\title{
ANALISIS KINERJA RENCANA BUNDARAN DENGAN PENDEKATAN SIMULASI MIKRO
}

\author{
(A Performance Analysis of Roundabout by Using Micro Simulation)
}

\author{
Tri Sudibyo ${ }^{1}$, Erizal $^{1}$, Purwo Mahardi ${ }^{2}$, Muhammad Fauzan ${ }^{1}$, dan Heriansyah Putra ${ }^{1}$ \\ ${ }^{1}$ Departemen Teknik Sipil dan Lingkungan, Fakultas Teknologi Pertanian, Institut Pertanian Bogor. Jl. \\ Raya Dramaga, Kampus IPB Dramaga, PO BOX 220, Bogor, Jawa Barat Indonesia \\ ${ }^{2}$ Jurusan Teknik Sipil, Universitas Negeri Surabaya, Jl. Ketintang, Gayungan, Surabaya, Indonesia \\ * Penulis korespondensi: tri.sudibyo@apps.ipb.ac.id
}

Diterima: 30 Juli 2019

Disetujui: 08 Agustus 2019

\begin{abstract}
Urban road network typically consists of many intersections which commonly lead to traffic problems. In relatively low traffic, a simple priority intersection will be sufficient and lead no traffic problem without necessarily implement traffic lights, roundabout or others. In an urban area where traffic demands are high, intersections need to be treated with an accurate traffic engineering approach. There are many different approaches to reduce the traffic problem in intersection including traffic light, roundabout, or interchange. Cimahpar Raya street and Indobaso intersections are urban areas in Bogor city with the high demand for transportation and often having a congestion problem in peak hour. The Office of Public Works and Spatial Planning (PUPR) of Bogor city plans to develop and change the Indobaso intersection to be a roundabout, while also increasing the lane width of the approaching roads. This study was conducted to assess the performance changes of the Indobaso intersection improvement by developing a traffic model of the intersection. The planned roundabout and lane width improvement significantly reduce the traffic delays by $90,07 \%$, reduce travel time by $51,76 \%$, improve average speed by $83,77 \%$, and reduce the traffic density by $88,54 \%$ compared to the current condition of the intersection which lacks required lane road width and maneuver area.
\end{abstract}

Key words: urban road, intersection, traffic model

\section{PENDAHULUAN}

Perkotaan modern memiliki ciri pertumbuhan populasi yang permanen dalam wilayah yang relatif terbatas, sehingga mendorong pertumbuhan jumlah kendaraan dan kebutuhan pergerakan manusia dan barang. Pertumbuhan kapasitas jalan tidak mungkin mengikuti pertumbuhan kendaraan pribadi, dimana kendaraan pribadi memiliki konsekuensi yang tidak diinginkan seperti kehilangan waktu, polusi, dan emisi (Guberinic et al 2008). Di banyak kota besar di Indonesia, laju pertumbuhan lalu lintas yang jauh lebih tinggi dari pembangunan jaringan jalan baru menyebabkan kemacetan
(Sudibyo, 2016). Pertumbuhan ekonomi menyebabkan mobilitas seseorang meningkat sehingga kebutuhan pergerakannya pun meningkat melebihi kapasitas sistem prasarana transportasi yang ada (Tamin, 2000).

Di jaringan jalan perkotaan sering ditemui simpang yaitu pertemuan dua atau lebih ruas jalan yang saling berpotongan, dimana permasalahan lalu lintas sering terjadi pada titik ini. Pada simpang dengan arus kendaraan besar pertemuan antar ruas jalan dapat ditingkatkan menjadi tidak sebidang untuk menghilangkan konflik pergerakan dan menghindari masalah kemacetan. Namun pembangunan simpang tidak sebidang berbiaya sangat tinggi 
dibanding dengan rekayasa lain sehingga merupakan pilihan terakhir. Sebagaimana tiap pembangunan infrastruktur, pembangunan simpang tidak sebidang harus memperhatikan perbandingan keuntungan dengan biaya investasinya, sehingga tidak semua simpang sesuai untuk diterapkan menjadi simpang tidak sebidang. Tanpa harus menjadi simpang tidak sebidang, terdapat beberapa alternatif peningkatan simpang tidak bersinyal seperti simpang bersinyal, bundaran, maupun kombinasi bundaran dan simpang bersinyal.

Kota Bogor merupakan salah satu kota satelit Jakarta dan terdapat aneka kegiatan di dalamnya seperti perdagangan dan jasa, pusat perbelanjaan, wisata belanja, dan permukiman. Dengan fungsi dan peruntukan kota tersebut menjadikan permintaan transportasi kota Bogor relatif besar, termasuk di titik dimana wilayah studi dalam penelitian ini dilakukan.

Simpang Jalan Raya Cimahpar dengan Jalan R. Hanafiah dan Jalan Babakan Indobaso yang sering disebut simpang Indobaso merupakan salah satu simpang di Kota Bogor yang sering terjadi kemacetan. Lokasi ruas jalan dan simpang ini tersaji pada Gambar 1.
Dengan padatnya tingkat hunian dan perumahan, banyak dan beragamnya kegiatan ekonomi dan usaha masyarakat di ruas Jalan Raya Cimahpar, dan fungsinya yang penting sebagai penghubung wilayah Cimahpar, Kecamatan Bogor Timur dan Kecamatan Sentul menuju pusat kota Bogor, mendorong tingginya arus lalu lintas yang melewati ruas jalan ini. Simpang Indobaso memiliki dimensi yang relatif sempit dibanding dengan arus lalu lintas yang harus dilayaninya terutama pada jam puncak. Kondisi ini memicu terjadinya kemacetan yang sering menjadi traffic jam atau kondisi mengunci pada jam puncak.

Pemerintah Kota Bogor melalui Dinas Pekerjaan Umum dan Penataan Ruang (PUPR) berencana meningkatkan simpang Indobaso menjadi bundaran, sekaligus peningkatan lebar ruas jalan pendekatnya. Studi ini dilakukan untuk menilai perubahan kinerja simpang Indobaso dengan adanya pembangunan tersebut.

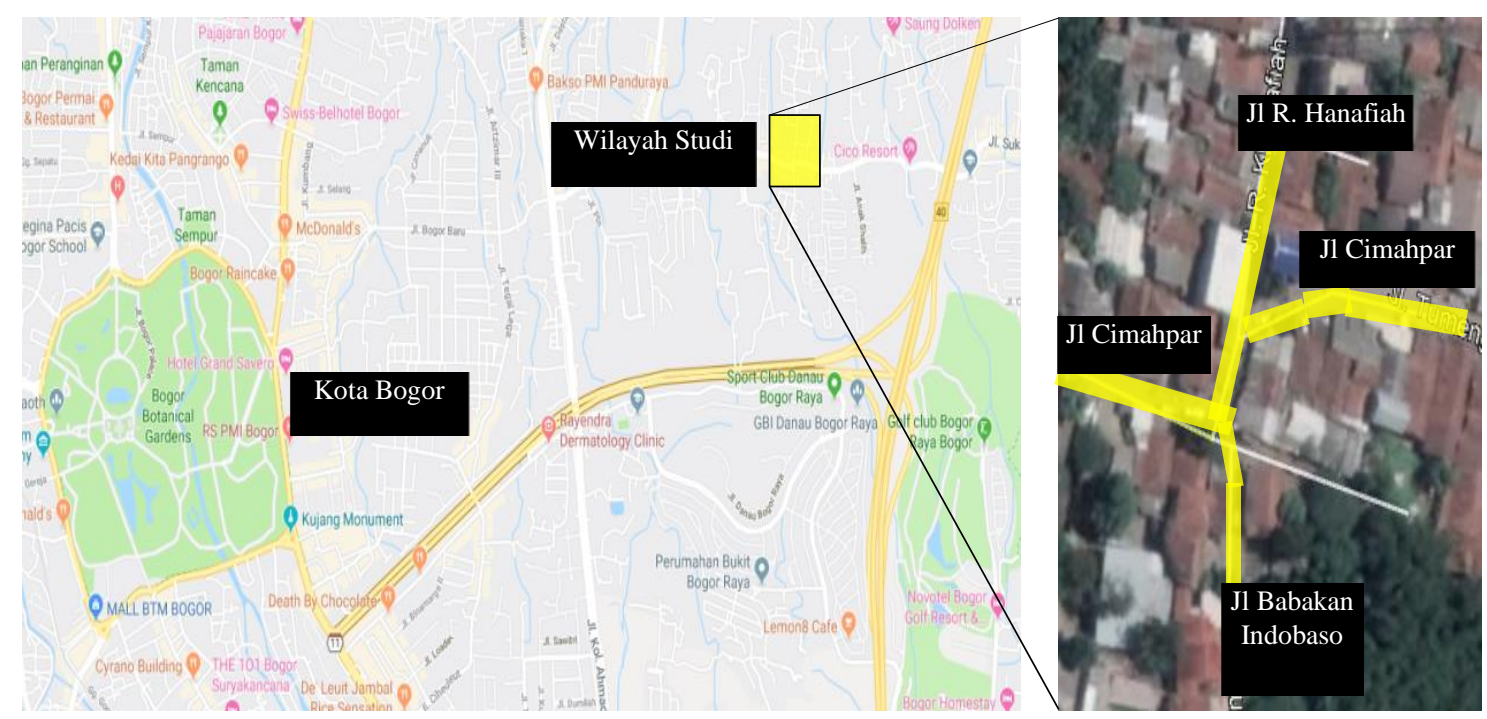

Gambar 1 Wilayah Studi di Simpang Indobaso, Cimahpar, Bogor Utara 

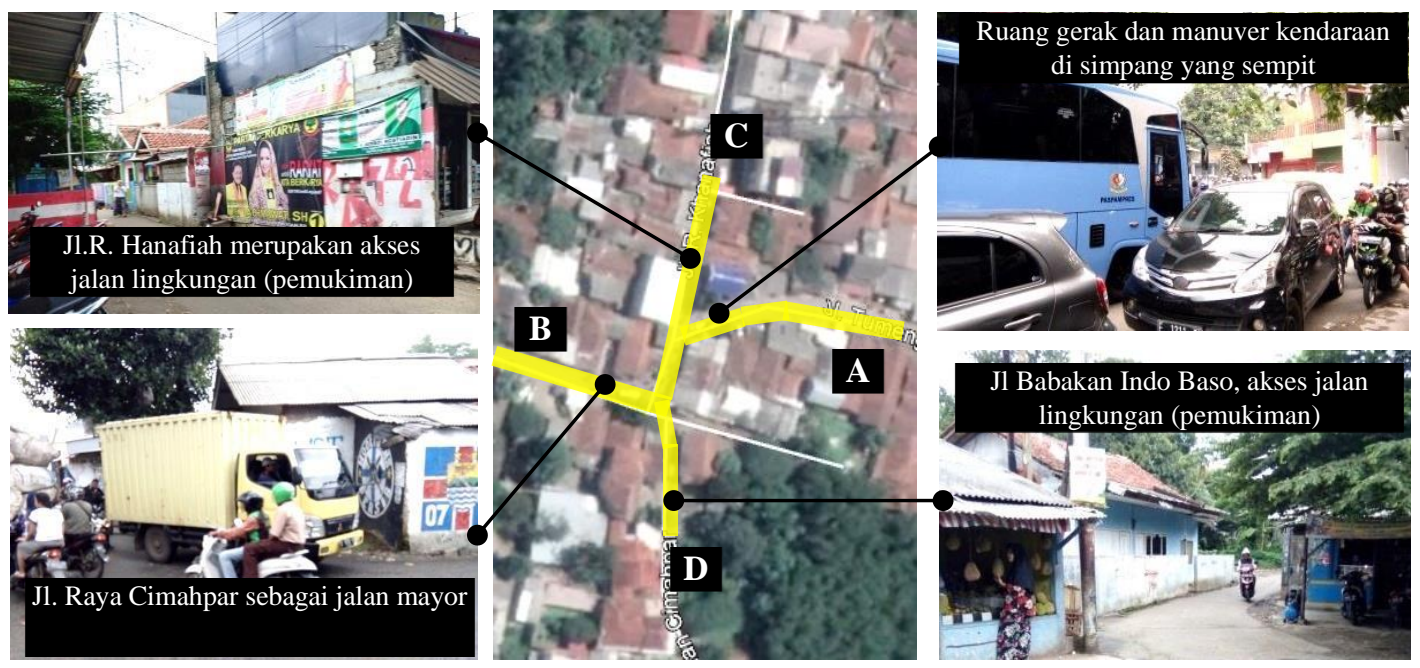

Gambar 2 Gambaran Kondisi Lalu lintas Wilayah Studi

\section{METODOLOGI}

Dalam penelitian ini dilakukan pembangunan model lalu lintas dalam skala mikro untuk menganalisis perbedaan kinerja diantara dua rekayasa yang dilakukan pada wilayah studi. Wilayah studi pada penelitian ini adalah simpang Indobaso, Cimahpar, Bogor Utara, Kota Bogor, dengan pengambilan data dilakukan pada bulan Desember 2018 Model mikro dibangun pada aplikasi Aimsun, untuk diperoleh prediksi perubahan kinerja lalu lintas pada jaringan jalan yang dikaji sesuai batas wilayah studi.

Model adalah cara untuk mengusulkan secara efisien beberapa skenario alternatif tanpa perlu bereksperimen langsung di lapangan. Simulasi dapat dianggap sebagai percobaan pada sistem riil yang dilakukan melalui model (TSS, 2008). Dengan analisis berdasarkan hasil pemodelan, diperlukan langkah pengecekan error (kesalahan), kalibrasi dan validasi untuk memastikan model yang dibangun telah paling representatif menggambarkan kondisi lapangan. Tahap pengecekan error merupakan langkah awal untuk memverifikasi apakah model memiliki kesalahan atau ketidak sesuaian.
Bentuk kesalahan yang diuji meliputi arah pergerakan kendaraan, jenis kendaraan yang dimodelkan, dan perilaku individu kendaraan. Tahapan setelah pengecekan error adalah kalibrasi, yaitu penyesuaian parameter model sehingga didapatkan pergerakan lalu lintas yang paling mendekati kondisi lapangan. Tahap berikutnya adalah validasi yang merupakan tahap akhir dari proses pemeriksaan model yaitu memastikan nilai-nilai parameter model telah sesuai dengan yang diharapkan, dimana dilakukan perbandingan parameter model dengan parameter lapangan. Parameter ini meliputi diantaranya arus kendaraan, kecepatan, waktu perjalanan, dan tundaan.

Mengacu kepada MKJI 1997 kapasitas simpang tidak bersinyal dihitung dengan persamaan berikut:

$C_{S T B}=C_{O} \times F_{W} \times F_{M} \times F_{C S} \times F_{R S U}$

$$
\mathrm{x} F_{L T} \times F_{R T} \times F_{M I}
$$

$\mathrm{C}_{\text {STB }}$ merupakan nilai kapasitas simpang tidak bersinyal dengan berbagai faktor koreksi mempengaruhi nilai kapasitas akhirnya. $F_{C S}$ adalah faktor penyesuaian ukuran kota, $F_{\text {LT }}$ adalah Faktor penyesuaian belok kiri $=0.84+1.61 \mathrm{P}_{\mathrm{LT}}$, $F_{R T}$ adalah Faktor penyesuaian belok kanan $=1.09-0.922 \mathrm{P}_{\mathrm{RT}}, \mathrm{F}_{\mathrm{MI}}$ adalah Faktor penyesuaian rasio arus jalan minor dengan 
nilai $\mathrm{F}_{\mathrm{MI}}=16.6 \mathrm{P}_{\mathrm{MI}}^{4}-3.3 \mathrm{P}_{\mathrm{MI}^{3}}+25.3 \mathrm{P}_{\mathrm{MI}}^{2}-$ $8.6 \mathrm{P}_{\mathrm{MI}}+1.95$ untuk $\mathrm{P}_{\mathrm{MI}}=0.1-0.3 ; \mathrm{F}_{\mathrm{MI}}=$ $1.11 \mathrm{P}_{\mathrm{MI}}^{2}-1.11 \mathrm{P}_{\mathrm{MI}}+1.1$ untuk $\mathrm{P}_{\mathrm{MI}}=0.3$ 0.5, dan $\mathrm{F}_{\mathrm{MI}}=-0.555 \mathrm{P}_{\mathrm{MI}}^{2}+0.555 \mathrm{P}_{\mathrm{MI}}+0.69$ untuk $\mathrm{P}_{\mathrm{MI}}=0.5-0.9$.

Nilai kapasitas merupakan parameter utama yang berperan dalam memberikan nilai akhir tingkat pelayanan, dimana rasio dari total volume kendaraan yang melintas $\left(\mathrm{Q}_{\text {tot }}\right)$ di simpang tersebut dengan kapasitas akan memberikan nilai derajat kejenuhan DS (Degree of Saturation $)$, atau DS = Qtot / C (Dirjen BM 1997).

Parameter kinerja lalu lintas lain yang dapat diperoleh adalah tundaan lalu lintas $\mathrm{DT}_{\mathrm{LL}}$, tundaan geometrik DG, dan total tundaan simpang D yang merupakan penjumlahan dari $\mathrm{DT}_{\mathrm{LL}}$ dan DG. Turunan berikutnya adalah peluang antrian $(\mathrm{QP} \%)$ yang merupakan peluang terjadinya antrian kendaraan akibat tundaan pada simpang.

Untuk dapat diterapkan bundaran dalam menangani simpang, dilakukan analisis kinerja bagian jalinan lalu lintas yang meliputi $\mathrm{C}$ adalah kapasitas, DS adalah derajat kejenuhan, $\mathrm{V}=$ kecepatan kendaraan dan TT adalah waktu tempuh kendaraan.

$\mathrm{C}=135 \times W w^{1.3} \times\left(1+\frac{W_{E}}{W_{w}}\right)^{1.5} \times F_{C S}$

$\mathrm{x}\left(1-\frac{P_{w}}{3}\right)^{0.5} \mathrm{x}\left(1+\frac{W_{w}}{L_{w}}\right)^{-1.8} \mathrm{x} F_{R S U}$

$D S=Q_{s m p} / C$

$V=V_{O} \times 0.5 \times\left(1+(1-D S)^{0.5}\right.$

$T T=L_{w} \times 3.6 / V$

\section{HASIL DAN PEMBAHASAN}

Simpang pada wilayah studi terdiri atas 4 (empat) pendekat yaitu Jalan Raya Cimahpar (Barat dan Timur), Jalan Babakan Indobaso dan Jalan R. Hanafiah, yang kemudian diberikan kode pendekat masing-masing B, A, D dan C sebagaimana Gambar 2.

Survey-survey geometrik jalan dilakukan pada badan simpang dan setiap lengan pendekatnya. Survey lalu lintas dilakukan dalam klasifikasi kendaraan ringan, kendaraan berat, motor dan kendaraan tidak bermotor pada setiap lengan simpang. Survey sampling waktu tempuh dan rataan kecepatan dilakukan pada setiap jenis kendaraan. Seluruh survey dilakukan pada hari kerja dan hari libur dimana puncak arus dan kemacetan terjadi pada hari kerja. Hasil survey lalu lintas jam puncak tersaji dalam Tabel 1 dan Tabel 2.

Hasil survey geometrik dituangkan dalam gambar model jaringan jalan sebagaimana tersaji dalam Gambar 3. Model lalu lintas dibangun berdasarkan survey lalu lintas, dengan terlebih dahulu dibangun model kondisi eksisting. Validasi model dilakukan dengan data panjang antrian dan rataan kecepatan. Model lalu lintas yang telah tervalidasi menjadi dasar dalam pembangunan model rencana bundaran. Rencana bundaran mengacu pada dokumen rencana pembangunan Dinas Pekerjaan Umum dan Penataan Ruang Kota Bogor tahun 2018. Model jaringan jalan baru dengan implementasi bundaran tersaji dalam Gambar 4. Rencana bundaran memiliki dimensi radius pulau lalu lintas di tengah sebesar 5 meter, lebar lajur 6 meter, radius putar lalu lintas di tengah jalur 8 meter. Peningkatan ruas jalan pendekat berupa pembangunan perkerasan beton untuk menggantikan jalan aspal. Peningkatan ruas jalan juga merubah lebar jalan dari kondisi saat ini 5,5 meter menjadi 6-7 meter. Mengacu pada MKJI 1997, peningkatan lebar jalan ini dapat mengurangi faktor reduksi kecepatan sehingga memungkinkan bertambahnya rataan kecepatan tempuh lalu lintas. 
Tabel 1 Hasil Survey Volume Jam Puncak Simpang

\begin{tabular}{|c|c|c|c|c|c|c|c|c|c|c|c|c|c|}
\hline \multirow{2}{*}{\multicolumn{2}{|c|}{ Tipe Kendaraan }} & \multicolumn{12}{|c|}{ Pendekat } \\
\hline & & \multicolumn{3}{|c|}{ A } & \multicolumn{3}{|c|}{ B } & \multicolumn{3}{|c|}{$\mathrm{C}$} & \multicolumn{3}{|c|}{ D } \\
\hline & & LT & ST & RT & LT & ST & RT & LT & ST & RT & LT & ST & RT \\
\hline \multirow{2}{*}{$\begin{array}{c}\mathrm{LV} \\
(11,67 \%)\end{array}$} & $\begin{array}{c}\mathrm{emp}=1,0 \\
\mathrm{smp} / \mathrm{jam}\end{array}$ & 40 & 216 & 42 & 33 & 129 & 27 & 5 & 2 & 6 & 5 & 2 & 4 \\
\hline & Kend/jam & 40 & 216 & 42 & 33 & 129 & 27 & 5 & 2 & 6 & 5 & 2 & 4 \\
\hline \multirow{2}{*}{$\begin{array}{c}\mathrm{HV} \\
(0,42 \%)\end{array}$} & $\begin{array}{c}\mathrm{emp}=1,3 \\
\mathrm{smp} / \mathrm{jam}\end{array}$ & 3 & 9 & 2 & 2 & 5 & 1 & 0 & 0 & 0 & 0 & 0 & 0 \\
\hline & Kend/jam & 2 & 7 & 1 & 2 & 4 & 1 & 0 & 0 & 0 & 0 & 0 & 0 \\
\hline \multirow{2}{*}{$\begin{array}{c}\mathrm{MC} \\
(84,8 \%)\end{array}$} & $\begin{array}{c}\mathrm{emp}=0,5 \\
\mathrm{smp} / \mathrm{jam}\end{array}$ & 89 & 420 & 90 & 70 & 320 & 67 & 46 & 12 & 44 & 29 & 11 & 26 \\
\hline & Kend/jam & 177 & 839 & 180 & 140 & 641 & 134 & 92 & 23 & 88 & 57 & 22 & 53 \\
\hline $\mathrm{UM}$ & Kend/jam & 2 & 3 & 2 & 0 & 1 & 0 & 0 & 0 & 1 & 1 & 1 & 1 \\
\hline \multirow{2}{*}{ MV } & $\mathrm{smp} / \mathrm{jam}$ & 126 & 612 & 129 & 100 & 446 & 133 & 56 & 14 & 54 & 35 & 14 & 33 \\
\hline & Kend/jam & 219 & 1062 & 224 & 174 & 774 & 230 & 97 & 25 & 94 & 62 & 24 & 57 \\
\hline \multicolumn{2}{|c|}{ Qdh } & \multicolumn{6}{|c|}{$\begin{array}{c}3038 \\
\text { kendaraan/jam }\end{array}$} & \multicolumn{6}{|c|}{$\begin{array}{c}1752 \\
\text { smp/jam }\end{array}$} \\
\hline \multicolumn{2}{|c|}{ Faktor $\mathrm{K}$} & \multicolumn{12}{|c|}{0,09} \\
\hline \multicolumn{2}{|c|}{ LHRT } & \multicolumn{6}{|c|}{$\begin{array}{c}33753 \\
\text { kendaraan/hari } \\
\end{array}$} & \multicolumn{6}{|c|}{$\begin{array}{c}19471 \\
\text { smp/hari }\end{array}$} \\
\hline
\end{tabular}

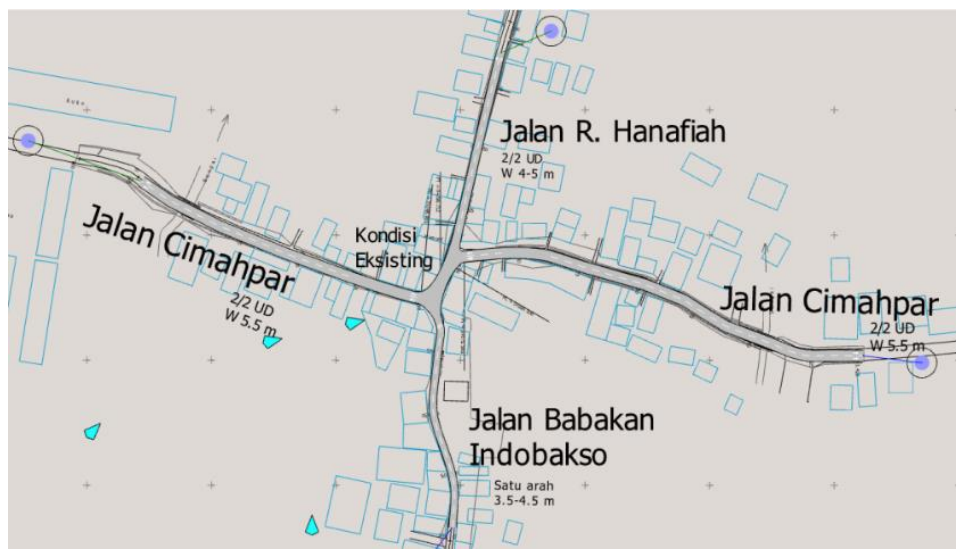

Gambar 3 Model Aimsun Jaringan Jalan Eksisting dalam Batas

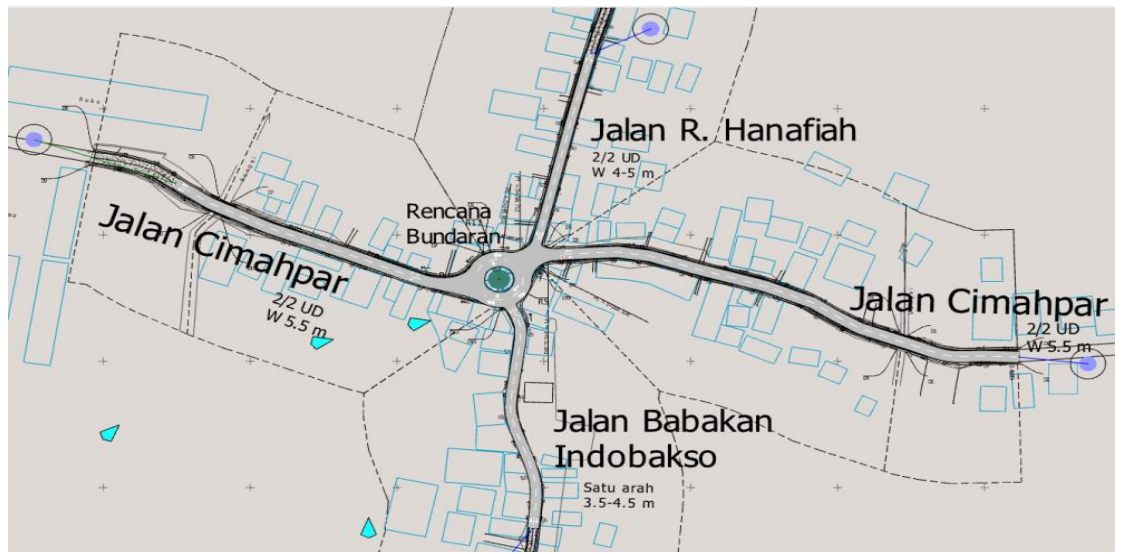

Gambar 4 Model Aimsun Rencana Bundaran dalam Batas Wilavah Studi 
Jalan Cimahpar bertipe 2/2 UD dengan lebar lajur 2 × 2,75 meter, Jalan R. Hanafiah bertipe $2 / 2$ UD dengan total lebar 4-5 meter, sedangkan Jalan Babakan Indobaso merupakan jalan sempit dengan total lebar 3,5-4,5 meter. Seluruh ruas jalan memiliki dimensi yang cukup untuk melintas kendaraan LV kedua arah kecuali Jalan Babakan Indobaso.

Dari hasil survey geometrik dan dari karakteristik lalu lintas menunjukkan ruas jalan Raya Cimahpar merupakan jalan mayor dan memiliki arus kendaraan terbesar. Ruas Jalan R. Hanafiah dan Jalan Babakan Indobaso terkategori jalan minor. Jalan minor dimodelkan untuk dapat memberikan prioritas pergerakan kepada jalan mayor.

\section{Arus Lalu lintas}

Pada kondisi eksisting, arus lalu lintas terbesar adalah di Jalan Cimahpar dengan hasil simulasi berdasarkan data survey didapatkan berkisar pada 1302 kendaraan/jam dari timur dan 1080 kendaraan/jam dari barat. Arus dari jalan R. Hanafiah dan Jalan Babakan Indobakso relatif kecil yaitu berkisar pada 140 - 360 kendaraan/jam.

Pembangunan bundaran di lokasi memberikan sedikit perbedaan dari total arus lalu lintas yang melintas dibandingkan dengan kondisi eksisting. Total kendaraan melintas di Jalan Cimahpar sebesar 1398 kendaraan/jam (dari timur) dan 1218 kendaraan/jam (dari barat) atau rata-rata naik sekitar 100-200 kendaraan per jam. Kenaikan total flow dalam satu jam ini dapat terjadi karena arus lalu lintas lebih lancar yang secara visual dari hasil simulasi terlihat dari tidak adanya penumpukan kendaraan di bundaran. Kondisi ini memungkinkan jumlah kendaraan yang dapat melintas dalam satu jam pada titik ini pun meningkat.

\section{Kepadatan Lalu lintas}

Hasil model pada kondisi eksisting menggambarkan kepadatan tertinggi terjadi di ruas jalan Cimahpar dari arah timur yaitu sebesar 98 kendaraan $/ \mathrm{km}$. Kepadatan ini terkonsentrasi di mulut simpang sebelum memasuki simpang sebagai akibat dari menurunnya kecepatan dan antrian kendaraan untuk dapat masuk ke ruang simpang yang sempit.

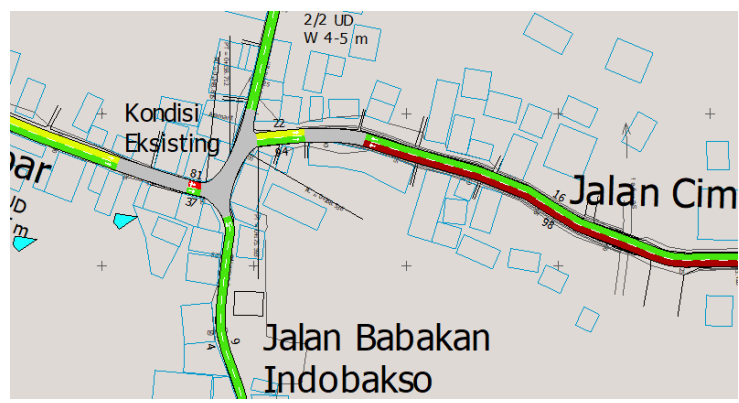

(a) Kondisi eksisting kepadatan terjadi di pendekat Timur Jalan Cimahpar

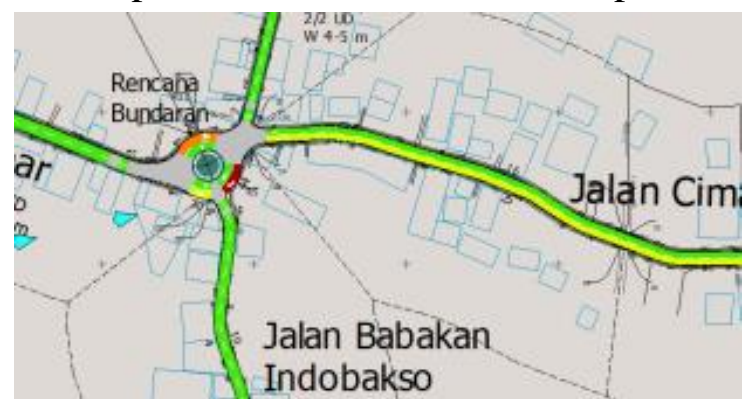

(b) Implementasi bundaran mengurangi kepadatan secara signifikan

Gambar 6 Perbedaan Tingkat Kepadatan

Kepadatan dari barat sebesar 22 kendaraan $/ \mathrm{km}$. Kepadatan ini terjadi karena antrian pada mulut simpang sehingga kendaraan mengantri sehingga kepadatan meningkat.

Model lalu lintas pada pembangunan bundaran memberikan hasil simulasi kepadatan tertinggi masih di ruas jalan yang sama, namun dengan adanya bundaran tingkat kelancaran pergerakan kendaraan meningkat sehingga antrian berkurang. Antrian berkurang memberikan nilai kepadatan yang juga menurun. 


\section{Tundaan}

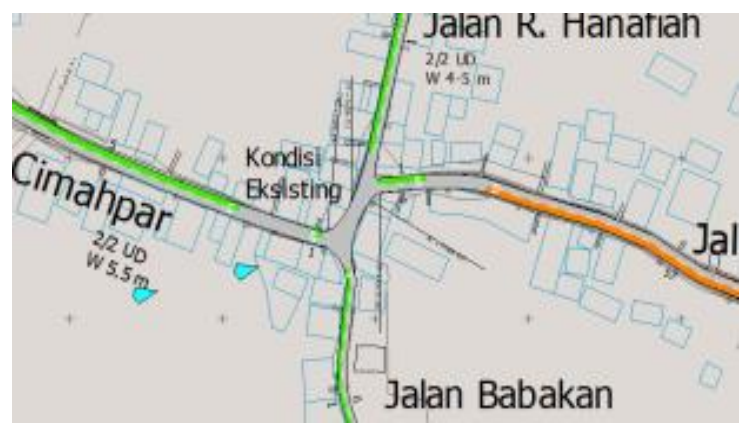

(a) Di kondisi eksisting tundaan terjadi di pendekat Timur Jalan Cimahpar

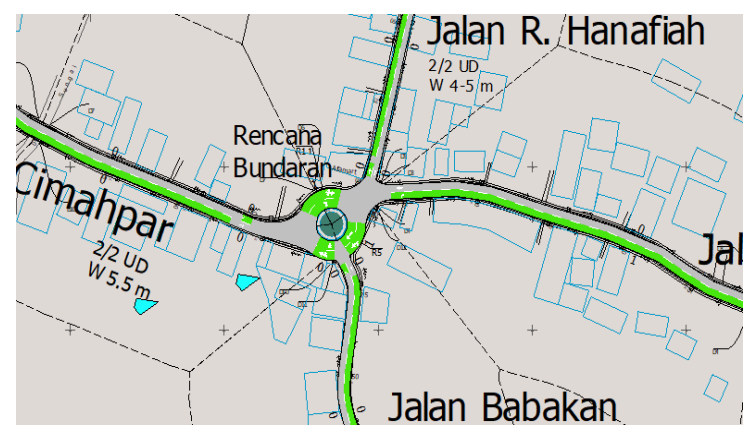

(b) Implementasi bundaran mengurangi tundaan secara signifikan

Gambar 7 Perbedaan Besaran Tundaan

Ruas jalan pada kondisi eksisting yang sempit dengan bentuk geometrik simpang yang tidak ideal mengakibatkan kendaraan menurukan kecepatan agar dapat bermanuver dan menghindari tabrak dari kendaraan arah berlawanan. Kondisi ini memberikan nilai tundaan tertinggi terjadi di jalan Cimahpar disebabkan oleh tingginya arus yang melewati ruas jalan utama ini. Rataan tundaan tercatat 117,46 $\operatorname{detik} / \mathrm{km}$.

Perbaikan simpang menjadi bundaran meningkatkan kelancaran berlalu lintas dimana potensi tundaan jauh menurun menjadi $11,66 \mathrm{detik} / \mathrm{km}$.
Tabel 2 Rataan Kecepatan Lalu-lintas Jam Puncak

\begin{tabular}{|c|c|c|c|}
\hline $\begin{array}{l}\text { Arah } \\
\text { Lalu- } \\
\text { lintas }\end{array}$ & $\begin{array}{c}\text { Jam } \\
\text { Survai }\end{array}$ & $\begin{array}{c}\text { Jenis } \\
\text { Kendaraan }\end{array}$ & $\begin{array}{c}\text { Kecepata } \\
\mathbf{n} \\
(\mathrm{Km} / \mathrm{Jam} \\
)\end{array}$ \\
\hline \multirow{4}{*}{ A-B } & \multirow{3}{*}{$\begin{array}{l}16.00- \\
18.00\end{array}$} & $\mathrm{LV}$ & 14.69 \\
\hline & & $\mathrm{HV}$ & 13.09 \\
\hline & & $\mathrm{MC}$ & 24.40 \\
\hline & \multicolumn{2}{|c|}{ Rataan } & 17.39 \\
\hline \multirow{4}{*}{ A-C } & \multirow{3}{*}{$\begin{array}{c}16.00- \\
18.00\end{array}$} & $\mathrm{LV}$ & 14.51 \\
\hline & & $\mathrm{HV}$ & - \\
\hline & & $\mathrm{MC}$ & 19.47 \\
\hline & \multicolumn{2}{|c|}{ Rataan } & 16.99 \\
\hline \multirow{4}{*}{ A-D } & \multirow{3}{*}{$\begin{array}{l}16.00- \\
18.00\end{array}$} & LV & 17.46 \\
\hline & & $\mathrm{HV}$ & - \\
\hline & & $\mathrm{MC}$ & 17.11 \\
\hline & \multicolumn{2}{|c|}{ Rataan } & 17.29 \\
\hline \multirow{4}{*}{ B-C } & \multirow{3}{*}{$\begin{array}{c}16.00- \\
18.00\end{array}$} & $\mathrm{LV}$ & 11.38 \\
\hline & & $\mathrm{HV}$ & - \\
\hline & & $\mathrm{MC}$ & 18.27 \\
\hline & \multicolumn{2}{|c|}{ Rataan } & 14.83 \\
\hline \multirow{4}{*}{ B-D } & \multirow{3}{*}{$\begin{array}{c}16.00- \\
18.00\end{array}$} & $\mathrm{LV}$ & 11.23 \\
\hline & & $\mathrm{HV}$ & - \\
\hline & & $\mathrm{MC}$ & 20.26 \\
\hline & \multicolumn{2}{|c|}{ Rataan } & 15.75 \\
\hline \multirow{4}{*}{ C-D } & \multirow{3}{*}{$\begin{array}{c}16.00- \\
18.00\end{array}$} & $\mathrm{LV}$ & 8.05 \\
\hline & & $\mathrm{HV}$ & - \\
\hline & & $\mathrm{MC}$ & 18.13 \\
\hline & \multicolumn{2}{|c|}{ Rataan } & 13.09 \\
\hline
\end{tabular}

\section{Kecepatan tempuh}

Pada kondisi eksisting, jam puncak lalu lintas memberikan kecepatan terendah di ruas jalan Cimahpar baik pada pedekat timur maupun barat. 


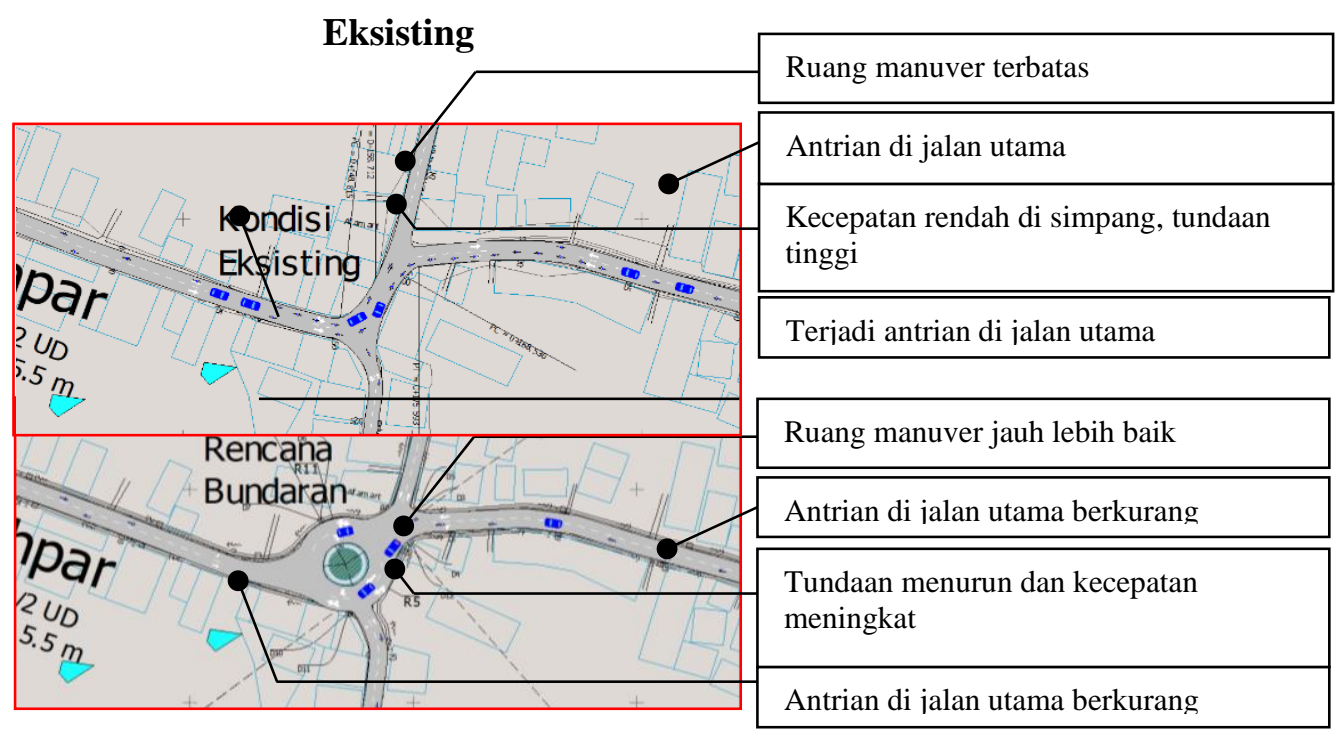

Gambar 8 Simulasi Perbedaan Kinerja Simpang Eksisting dan Rencana Bundaran

Dari timur kecepatan terukur ratarata pada $7 \mathrm{~km} / \mathrm{jam}$, sedangkan dari barat pada mulut simpang $8 \mathrm{~km} / \mathrm{jam}$. Kecepatan yang rendah terjadi karena antrian di simpang tersebut. Setelah dibangunnya bundaran, arus lalu lintas menjadi lebih lancar dan tercatat kecepatan hasil simulasi di Jalan Cimahpar baik dari barat maupun dari timur meningkat yaitu $29 \mathrm{~km} / \mathrm{jam}$ dan $39 \mathrm{~km} / \mathrm{jam}$.

Dari simulasi kondisi lalu lintas di wilayah studi ini terdapat hubungan yang erat antara kecepatan, arus lalu lintas, tundaan, waktu tempuh dan kepadatan lalu lintas. Pada kondisi eksisting, disebabkan oleh sempitnya ruang gerak pada simpang Indobaso, kendaraan yang semula melaju dengan kecepatan relatif tinggi harus mengurangi kecepatannya saat masuk ke mulut simpang.

Dengan arus lalu lintas yang tinggi pada jam puncak (2674 kendaraan/jam) dan kecepatan yang rendah (16,33 $\mathrm{km} / \mathrm{jam}$ ), mengakibatkan sering terjadi traffic jam atau kondisi mengunci baik ringan dan cepat terurai maupun lama dan mengakibatkan antrian lebih panjang. Kondisi ini terukur sebagai tundaan sehingga pada simulasi kondisi eksisting sering didapatkan nilai rata-rata tundaan yang relatif tinggi $(117,46 \mathrm{detik} / \mathrm{km})$. Pada saat yang sama, dengan kecepatan yang rendah dan volume tinggi, terjadi antrian kendaraan sehingga jarak antar kendaraan mengecil dan terukur kepadatan lalu lintas menjadi tinggi $(27,64$ kendaraan/km) yang terkonsentrasi di mulut simpang, dengan waktu tempuh perjalanan juga tinggi $(252,52$ detik/km).

Tabel 3 Perbedaan Kondisi Eksisting dan Implementasi Bundaran

\begin{tabular}{|l|r|r|}
\hline \multicolumn{1}{|c|}{ Parameter } & Eksisting & Bundaran \\
\hline Tundaan (detik/km) \\
\hline Total & 117.46 & 11.66 \\
\hline LV \& HV & 142.92 & 17.93 \\
\hline MC & 112.47 & 10.44 \\
\hline Kepadatan (kendaraan/km) \\
\hline Total & 27.64 & 14.66 \\
\hline LV \& HV & 4.92 & 2.37 \\
\hline MC & 22.72 & 12.29 \\
\hline Arus Lalu lintas (kendaraan/jam) \\
\hline Total & 2674 & 2930 \\
\hline LV \& HV & 438 & 477 \\
\hline MC & 2236 & 2453 \\
\hline Kecepatan (km/jam) \\
\hline
\end{tabular}




\begin{tabular}{|l|r|r|}
\hline \multicolumn{1}{|c|}{ Parameter } & Eksisting & Bundaran \\
\hline Total & 16.33 & 30.01 \\
\hline LV \& HV & 15.46 & 30.95 \\
\hline MC & 16.5 & 29.83 \\
\hline \multicolumn{2}{|c|}{ Waktu Tempuh (detik/km) } \\
\hline Total & 252.52 & 121.82 \\
\hline LV \& HV & 266.18 & 118.27 \\
\hline MC & 249.85 & 122.51 \\
\hline
\end{tabular}

Korelasi yang tinggi antar parameter juga terjadi pada kondisi dengan terbangunnya bundaran. Setelah terbangunnya bundaran, arus lalu lintas yang melintas dalam jaringan meningkat sebesar 9,6\% dibanding kondisi eksisting menjadi 2930 kendaran/jam. Pada kondisi ini kecepatan lalu lintas juga meningkat sebesar $83,77 \%$ menjadi $30,01 \mathrm{~km} / \mathrm{jam}$. Kondisi ini terjadi karena meningkatnya kelancaran manuver kendaraan karena ruang gerak yang lebih baik di titik simpang dengan terbangunnya bundaran. Manuver kendaraan yang lebih mudah memungkinkan kendaraan melaju dengan kecepatan lebih tinggi, sehingga antrian relatif jarang terjadi. Antrian yang tidak terjadi ini terukur sebagai delay atau tundaan yang kecil yaitu 11,66 detik/km, menurun sebesar $90,07 \%$ dibanding kondisi eksisting, sehingga secara keseluruhan jaringan kendaraan yang dapat melintas dalam satuan waktu yang sama menjadi lebih besar yang terukur dalam arus lalu lintas yang lebih tinggi dibanding kondisi eksisting. Pada saat yang sama, kondisi ini menyebabkan relatif tidak terjadinya antrian kendaraan sehingga kepadatan terukur 14,66 kendaraan $/ \mathrm{km}$, menurun sebesar $88,54 \%$ dibanding kondisi eksisting, dan waktu tempuh perjalanan juga terukur lebih rendah yaitu $121,82 \mathrm{detik} / \mathrm{km}$, menurun $51,76 \%$ bila dibanding kondisi eksisting.

\section{KESIMPULAN}

Berdasarkan hasil penelitian yang telah dilakukan, maka dapat disimpulkan bahwa:

1. Dari data dan pengamatan empiris dan dari simulasi model lalu lintas disimpulkan bahwa di wilayah studi yaitu simpang Indobaso, Cimahpar, Bogor, sering beresiko terjadi kemacetan sedang hingga kondisi mengunci pada jam puncak terutama bila kendaraan dimensi besar melintas.

2. Penerapan bundaran sebagaimana direncanakan oleh Pemerintah Kota Bogor dapat meningkatkan kinerja lalu lintas dan mengurangi resiko kemacetan.

3. Penerapan bundaran dapat menambah potensi arus lalu lintas yang dapat terlayani yaitu meningkat sebesar 9,6\%, meningkatkan rataan kecepatan lalu lintas sebesar 83,77\%, mengurangi waktu tempuh sebesar $51,76 \%$, menurunkan tundaan sebesar 90,77\%, dan mengurangi kepadatan sebesar $88,54 \%$.

4. Peningkatan kinerja simpang dan bundaran ini diperoleh dari simulasi model lalu lintas dalam kondisi berlalu lintas secara ideal, yaitu tanpa gangguan seperti mobil berhenti pada lajur lalu lintas, on street parking, kerusakan jalan, dan gangguan lain.

5. Perlu adanya penelitian lebih lanjut mengenai optimasi bundaran maupun studi bentuk implementasi rekayasa lalu lintas yang lain di simpang tersebut yang dapat meningkatkan kinerja lebih lanjut.

\section{DAFTAR PUSTAKA}

[BPS] Badan Pusat Statistik Kabupaten Bogor. 2014. Jumlah Penduduk Menurut Jenis Kelamin 2014. Bogor (ID): Badan Pusat Statistik.

[Dirjen BM] Departemen Pekerjaan Umum. 1997. Manual Kapasitas 
Jalan Indonesia. Direktorat Jenderal Bina Marga, Jakarta.

[KEMENHUB] Kementrian Perhubungan. 2015. Peraturan Menteri Perhubungan No 96 Tahun 2015 tentang Pedoman Pelaksanaan Kegiatan Manajemen dan Rekayasa Lalu Lintas. Jakarta.

[PUSJATAN] Pusat Penelitian dan Pengembangan Jalan dan Jembatan. 2015. Simpang tak Bersinyal dan Bagian Jalinan. Pedoman Kapasitas Jalan Indonesia (PKJI) 2015. Jakarta. Kementerian Pekerjaan Umum dan Perumahan Rakyat.

Guberinic, S., Senborn, G., and Lazic, B. (2008). Optimal Traffic Control Urban Intersection. CRC Press. Boca Raton, USA

Khisty J C dan Lall K B. 2005. Dasardasar Rekayasa Transportasi Jilid I. Jakarta. Erlangga.

Mendenhall. W, Robert J. Beaver and Barbara M. Beaver. 2009. Introduction to Probability \& Statistic 13th edition. Nelson Education. Ltd., Canada.

Ortúzar Juan de Dios. 2001. Modeling Transport, 3rd edition. Wiley.

Sudibyo, T. dan Widyarti, M. 2016. Analisis Pengaruh Penyempitan Jalan (bottleneck) Terhadap Tingkat Pelayanan Jalan dengan Pendekatan Simulasi Mikro. Yogyakarta. Proceeding KoNTekS Vol.2: 483489.

Tamin, Ofyar Z. 2000. Perencanaan dan Pemodelan Transportasi, Edisi Kedua. Bandung. Penerbit ITB.

TSS-Transport Simulation Systems. 2008. Microsimulator and Mesosimulator in AIMSUN User's Manual. Barcelona. TSS.

US Department of Transportation. 2004. Traffic Analysis Toolbox Volume III: Guidelines for Applying Traffic Microsimulation Modeling Software, Research, Development, and
Technology. Turner-Fairbank Highway Research Center, USA 